\title{
Pengaruh Jenis Busi Terhadap Konsumsi Bahan Bakar Dan Emisi Gas Buang Pada Sepeda Motor Honda Revo Fit 110 cc
}

\author{
Wawan Trisnadi Putra1), Sudarno2), Yoyok Winardi3) \\ Universitas Muhammadiyah Ponorogo $0^{1,2,3)}$ \\ Jl. Budi Utomo 10 Ponorogo Jawa Timur \\ E-mail : wawantrisnadi@gmail.com¹)
}

\begin{abstract}
Abstrak
Tingkat panas busi adalah kemampuan busi untuk membawa panas dari ruang pembakaran keluar dari ujung busi ke shell busi. Semakin besar nilainya, panas lebih mudah dilepaskan. Penelitian ini menguji tiga jenis tingkat panas busi yaitu U20EPR9, U24EPR9, dan U27EPR9. Masing-masing busi diteliti konsumsi bahan bakar dan emisi gas buang dengan waktu 180 detik pada putaran mesin 1500, 2000, 2500, 3000, 3500, 4000, dan 4500. Berdasarkan hasil penelitian dapat disimpulkan bahwa penggunaan jenis busi berdasarkan tingkat panas pada sepeda motor Honda Revo Fit $110 \mathrm{cc}$ tahun 2012 berpengaruh terhadap konsumsi bahan bakar. Pada penggunaan busi U20EPR9 konsumsi bahan bakar secara total pada semua putaran mesin yang diujikan adalah sebesar 82,27 ml, sedangkan konsumsi bahan bakar busi U24EPR9 adalah 80,98 $\mathrm{ml}$ mengalami penurunan sebesar 1,5\% dibanding dengan busi U20EPR9. Pada pemakaian busi U27EPR9 konsumsi bahan bakar adalah 72,68 ml mengalami penurunan sebesar $11,6 \%$ dari busi U20EPR9. Sedangkan konsumsi bahan bakar pada busi U27EPR9 mengalami penurunan 10,2\% dari busi U24EPR9. Konsentrasi Karbon Monoksida terendah dihasilkan oleh busi U27EPR9 pada putaran $1500 \mathrm{rpm}$ sebesar $0,12 \%$. Konsentrasi Karbondioksida tertinggi dihasilkan oleh busi U27EPR9 pada putaran $4000 \mathrm{rpm}$ sebesar 1,27\%. Konsentrasi Hidrokarbon terendah dihasilkan oleh busi U20EPR9 pada putaran $4000 \mathrm{rpm}$ sebesar $16,29 \mathrm{ppm}$. Sedangkan konsentrasi Oksigen mengalami peningkatan yang signifikan pada penggunaan busi U20EPR9, peningkatan tertinggi sebesar 19,70\% didapatkan pada putaran 4000 rpm.
\end{abstract}

Kata kunci: Jenis Busi, Efisiensi, Emisi

\section{PENDAHULUAN}

Busi adalah salah satu komponen sepeda motor yang termasuk dalam sistem pengapian dan dipasang di kepala silinder. Voltase yang dihasilkan oleh coil pengapian (ignition coil) terjadi di antara elektroda pusat (center electrode) dan ujung dari busi (ground electrode), yang menghasilkan percikan. Percikan membakar udara/campuran bahan bakar dalam silinder (TTL1 Maintenance Training AHM, 2012:4-14).

Yang membedakan antara busi panas dan dingin pada konstruksi bodi busi adalah panjang insulator bawahnya. Pada busi dingin, insulatornya relatif lebih pendek dibandingkan insulator busi panas. Sehingga permukaan penampang yang berhubungan dengan api sangat kecil dan rute penyebaran panasnya lebih pendek, jadi penyebaran panasnya sangat baik dan suhu elektroda tengah tidak naik terlalu tinggi, oleh sebab itu jika dipakai busi dingin pre ignition lebih sulit terjadi. Sebaliknya karena busi panas mempunyai insulator bagian bawah yang lebih panjang, maka luas permukaan yang berhubungan dengan api lebih besar, rute penyebaran panas lebih panjang, akibatnya temperatur elektroda tengah naik cukup tinggi dan self-cleaning temperature dapat dicapai lebih cepat, meskipun pada kecepatan yang rendah dibandingkan dengan busi dingin.

Dari uraian latar belakang di atas dapat disimpulkan bahwa penelitian tingkat panas busi perlu dilakukan untuk membuktikan bahwa pergantian busi pada sepeda motor juga harus memperhatikan tingkat panas busi. Dalam penelitian ini, peneliti tertarik untuk 
mengkaji dan membandingkan pemakaian jenis busi sepeda motor empat langkah terhadap pengaruh konsumsi bahan bakar dan kadar emisi gas buang.

\section{DASAR TEORI}

Menurut tingkat kemampuan melepas panasnya, busi terbagi menjadi 2, yaitu:

\section{Busi Panas}

Busi yang kecepatan transfer panasnya lebih lambat. Artinya panas tersimpan pada busi dan lambat disalurkan keluar busi. Busi panas biasa dipakai pada kendaraan harian. Busi panas ini tidak diharapkan bekerja pada temperatur ruang bakar tinggi, bila temperatur ruang bakar mencapai sekitar $850{ }^{\circ} \mathrm{C}$, maka akan terjadi proses pre ignition, dimana bahan bakar akan menyala dengan sendirinya sebelum busi memercikkan bunga api.

Pre ignition ini adalah proses yang tidak diharapkan dalam siklus pembakaran motor 4 langkah tipe spark engine atau mesin dengan penyalaan busi. kondisi terjadinya pre ignition ini bisa dikatakan over heating (pemanasan extrem). Terjadinya pre ignition ini dapat merusak kinerja dari piston, valve, connecting rod, bahkan crankshaft atau poros engkol. Warna yang tampak pada busi bila terjadi pre ignition adalah putih pucat, bahkan dalam kondisi terburuk busi bisa meleleh.

Busi Dingin

Busi yang kecepatan transfer panasnya cepat. Artinya panas harus cepat disalurkan keluar busi. Busi dingin identik dengan busi racing yang harus melepas panas mesin dengan cepat. Busi dingin ini tidak diharapkan bekerja pada temperatur ruang bakar yang rendah. Jika temperatur ruang bakar terlalu rendah hingga dibawah $400{ }^{\circ} \mathrm{C}$, maka akan terjadi proses carbon fouling, dimana bahan bakar tidak mampu terbakar habis bahkan gagal pembakaran sehingga bahan bakar tadi akan menumpuk pada busi. Apabila suhu ruang bakar semakin rendah, maka terjadi miss fire atau ketidakmampuan busi membakar bahan bakar akibat suhu mesin tidak ideal.

Penumpukan endapan karbon ini semakin semakin lama akan menyebabkna tumpukan kerak karbon yang lama kelamaan menjadi keras dan akibatnya menjadi sumber panas kedua (arang) setelah busi dan hal inilah juga yang menyebabkan gejala detonasi atau knocking atau ledakan kedua setelah busi memercikkan bunga api. Gejala detonasi ini adalah proses pembakaran yang tidak diharapkan untuk mesin spark engine. Detonasi ini dapat menyebabkan kerusakan pada piston. Terjadinya carbon fouling ini dapat mempercepat umur pakai busi. Warna yang tampak pada busi bila terjadi carbon fouling adalah hitam kering.

Daerah tempat tinggal untuk daerah bersuhu dingin, seperti daerah pegunungan dan dataran tinggi, paling pas memakai busi panas. Sebab, pemakaian busi dingin akan mempercepat penumpukan kerak. Sedang, daerah panas macam tepi laut atau metropolis, lebih baik memakai busi dingin. Untuk mencegah terjadinya pre ignition atau pembakaran dini.

Perbandingan kompresi tinggi dan kapasitas mesin yang besar, sama-sama menimbulkan panas. Logikanya mudah, makin besar nilai kapasitas mesin, panas yang dikandung juga makin tinggi. Di sini busi juga menentukan kualitas pembakaran, dengan batasan diatas $150 \mathrm{cc}$, sebaiknya menggunakan busi tipe dingin. Dan mengingat, motor harian dirancang pabrikan menganut perbandingan kompresi rendah, maka suhu relatif rendah ke panas. Dan faktor kapasitas mesin yang sebaiknya dijadikan pedoman.

Oleh sebab masalah-masalah yang timbul diatas, maka perlunya memilih tingkat panas busi yang sesuai dengan kebutuhan sepeda motor kita.

\section{METODE PENELITIAN}

Jenis penelitian ini merupakan penelitian statistik inferensia. Menurut (Somantri Ating dan Sambas Ali Muhidin, 2006;19) metode statistika inferensia (inferential statistics) membahas mengenai cara menganalisis data serta mengambil kesimpulan (berkaitan dengan estimasi parameter dan pengujian hipotesis). Metode statistika inferensia berkaitan dengan 
analisis sebagian data sampai ke peramalan atau penarikan kesimpulan mengenai keseluruhan data.

\section{Teknik Analisis Data}

Analisa data menggunakan metode statistika parametrik (parametric statistics). Statistika parametrik merupakan bagian dari statistika inferensia yang mempertimbangkan nilai dari satu atau lebih parameter populasi. Statistika parametrik biasanya dihubungkan dengan data yang bersifat kuantitatif. Contoh analisis parametrik dalam statistika parametrik adalah Uji t (untuk satu dan dua sampel), Analisi ragam (ANOVA) Uji Korelasi Pearson, dan Uji regresi (F) (Somantri Ating dan Sambas Ali Muhidin, 2006;19-20).

Data yang diperoleh dari hasil penelitian dimasukkan ke dalam tabel, dan ditampilkan dalam bentuk grafik yang kemudian akan dianalisa dan ditarik kesimpulan. Sehingga dapat diketahui persentase konsumsi bahan bakar, dan kadar emisi gas buang sepeda motor dengan menggunakan berbagai jenis busi berdasarkan tingkat panas.

\section{Pengambilan Data}

Masing-masing busi diuji berdasarkan prosedur diatas. Data hasil percobaan akan menentukan konsumsi bahan bakar dan emisi gas buang yang dihasilkan. Data yang diperoleh dari hasil penelitian emisi gas buang dimasukkan ke dalam tabel, dan ditampilkan dalam bentuk grafik yang kemudian akan dianalisa dan ditarik kesimpulan. Sehingga dapat diketahui persentase kenaikan dan penurunan kadar emisi gas buang sepeda motor dengan menggunakan berbagai jenis busi berdasarkan tingkat panas.

\section{Analisa Data}

Dari data diatas akan diolah menggunakan program SPSS 18,0 dengan analisa Case Summaries diperoleh hasil sebagai berikut:
Tabel 1. Data Hasil Pengujian Konsumsi Bahan Bakar Busi U20EPR9, Busi U24EPR9, dan Busi U27EPR9

\begin{tabular}{|c|c|c|c|c|c|}
\hline & $\begin{array}{c}\text { Konsu } \\
\text { msi } \\
\text { Bahan } \\
\text { Bakar } \\
\text { Busi } \\
\text { U20EP } \\
\text { R9 } \\
\text { (ml) }\end{array}$ & $\begin{array}{c}\text { Konsu } \\
\text { msi } \\
\text { Bahan } \\
\text { Bakar } \\
\text { Busi } \\
\text { U24EP } \\
\text { R9 } \\
\text { (ml) }\end{array}$ & $\begin{array}{c}\text { Konsu } \\
\text { msi } \\
\text { Bahan } \\
\text { Bakar } \\
\text { Busi } \\
\text { U27EP } \\
\text { R9 } \\
\text { (ml) }\end{array}$ \\
\hline $\begin{array}{l}\text { Puta } \\
\text { ran }\end{array}$ & $\begin{array}{l}15 \\
00 \\
\end{array}$ & 1 & 8 & 7 & 7 \\
\hline \multirow[t]{25}{*}{$\begin{array}{l}\text { (rpm } \\
\text { ) }\end{array}$} & & 2 & 8 & 6 & 8 \\
\hline & & 3 & 6 & 7 & 8 \\
\hline & & 4 & 7 & 6 & 7 \\
\hline & & 5 & 7 & 7 & 6 \\
\hline & & 6 & 7 & 7 & 6 \\
\hline & & 7 & 6 & 8 & 6 \\
\hline & & $\begin{array}{l}\text { Tot } \\
\text { al } \\
\mathrm{N}\end{array}$ & 7 & 7 & 7 \\
\hline & \multicolumn{2}{|c|}{ Mean } & 7 & 6,857 & 6,857 \\
\hline & $\begin{array}{l}20 \\
00\end{array}$ & 1 & 9 & 11 & 8 \\
\hline & & 2 & 9 & 9 & 9 \\
\hline & & 3 & 9 & 9 & 8 \\
\hline & & 4 & 10 & 10 & 9 \\
\hline & & 5 & 10 & 9 & 8 \\
\hline & & 6 & 10 & 9 & 8 \\
\hline & & 7 & 10 & 10 & 9 \\
\hline & & $\begin{array}{l}\text { Tot } \\
\text { al } \\
\mathrm{N}\end{array}$ & 7 & 7 & 7 \\
\hline & & $\begin{array}{r}\mathrm{Me} \\
\text { an }\end{array}$ & 9,571 & 9,571 & 8,428 \\
\hline & $\begin{array}{l}25 \\
00\end{array}$ & 1 & 12 & 11 & 10 \\
\hline & & 2 & 10 & 12 & 11 \\
\hline & & 3 & 10 & 10 & 8 \\
\hline & & 4 & 10 & 11 & 9 \\
\hline & & 5 & 10 & 10 & 10 \\
\hline & & 6 & 10 & 11 & 8 \\
\hline & & 7 & 10 & 10 & 11 \\
\hline & & $\begin{array}{l}\text { Tot } \\
\text { al } \\
\mathrm{N}\end{array}$ & 7 & 7 & 7 \\
\hline
\end{tabular}




\begin{tabular}{|c|c|c|c|c|}
\hline & $\begin{array}{r}\mathrm{Me} \\
\text { an }\end{array}$ & $\begin{array}{r}10,28 \\
5\end{array}$ & $\begin{array}{r}10,71 \\
4\end{array}$ & 9,571 \\
\hline $\begin{array}{l}30 \\
00 \\
\end{array}$ & 1 & 14 & 11 & 10 \\
\hline & 2 & 10 & 12 & 11 \\
\hline & 3 & 11 & 13 & 8 \\
\hline & 4 & 12 & 12 & 9 \\
\hline & 5 & 13 & 13 & 10 \\
\hline & 6 & 10 & 11 & 8 \\
\hline & 7 & 12 & 12 & 11 \\
\hline & $\begin{array}{l}\text { Tot } \\
\text { al } \\
\mathrm{N}\end{array}$ & 7 & 7 & 7 \\
\hline & $\begin{array}{r}\mathrm{Me} \\
\text { an } \\
\end{array}$ & $\begin{array}{r}11,71 \\
4 \\
\end{array}$ & 12 & 9,571 \\
\hline $\begin{array}{l}35 \\
00\end{array}$ & 1 & 12 & 11 & 10 \\
\hline & 2 & 14 & 12 & 11 \\
\hline & 3 & 14 & 13 & 12 \\
\hline & 4 & 12 & 12 & 11 \\
\hline & 5 & 11 & 13 & 10 \\
\hline & 6 & 15 & 11 & 12 \\
\hline & 7 & 13 & 12 & 10 \\
\hline & $\begin{array}{l}\text { Tot } \\
\text { al } \\
\mathrm{N}\end{array}$ & 7 & 7 & 7 \\
\hline & $\begin{array}{r}\text { Me } \\
\text { an } \\
\end{array}$ & 13 & 12 & $\begin{array}{r}10,85 \\
7 \\
\end{array}$ \\
\hline $\begin{array}{l}40 \\
00\end{array}$ & 1 & 14 & 15 & 11 \\
\hline & 2 & 14 & 14 & 14 \\
\hline & 3 & 14 & 14 & 12 \\
\hline & 4 & 13 & 15 & 12 \\
\hline & 5 & 14 & 14 & 13 \\
\hline & 6 & 15 & 13 & 11 \\
\hline & 7 & 14 & 15 & 13 \\
\hline & $\begin{array}{l}\text { Tot } \\
\text { al } \\
\mathrm{N}\end{array}$ & 7 & 7 & 7 \\
\hline & $\begin{array}{r}\mathrm{Me} \\
\text { an }\end{array}$ & 14 & $\begin{array}{r}14,28 \\
5\end{array}$ & $\begin{array}{r}12,28 \\
5\end{array}$ \\
\hline $\begin{array}{l}45 \\
00\end{array}$ & 1 & 20 & 15 & 15 \\
\hline & 2 & 17 & 15 & 15 \\
\hline & 3 & 17 & 15 & 15 \\
\hline & 4 & 16 & 16 & 14 \\
\hline
\end{tabular}

\begin{tabular}{|l|l|l|r|r|r|}
\hline & & 5 & 15 & 17 & 16 \\
\hline & & 6 & 17 & 15 & 15 \\
\hline & & 7 & 15 & 16 & 16 \\
\hline & & Tot & & & \\
& al & & & \\
& & 7 & 7 & 7 \\
\hline & & Me & 16,71 & 15,57 & 15,14 \\
& & an & 4 & 1 & 2 \\
\hline
\end{tabular}

Secara umum dalam penelitian, pemakaian busi tipe dingin untuk sepeda motor Honda Revo Fit 110 cc tahun 2012 dapat menurunkan konsumsi bahan bakar di setiap putaran mesin.

Dari hasil penelitian dapat disimpulkan bahwa penggunaan busi jenis dingin (U27EPR9) dapat menurunkan konsumsi bahan bakar pada sepeda motor Honda Revo Fit 110 cc tahun 2012 secara signifikan. Rata-rata konsumsi bahan bakar pada setiap rpm dapat dilihat pada Gambar 2.

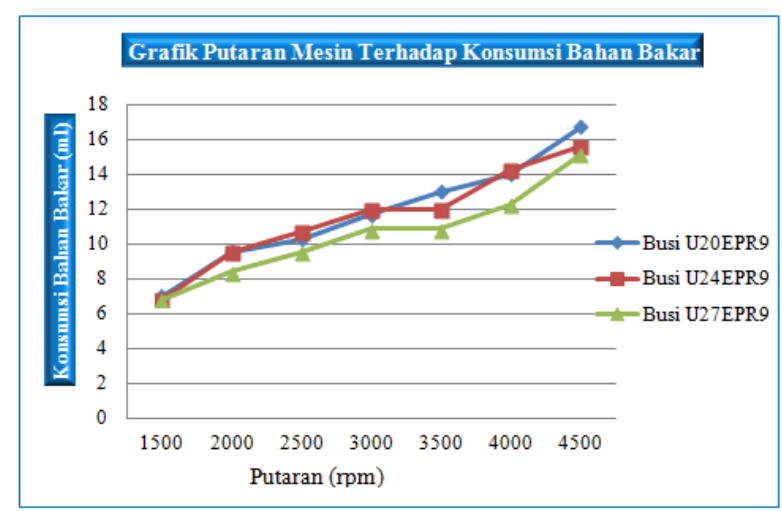

Gambar 2. Hubungan antara putaran mesin terhadap konsumsi bahan bakar

Secara umum dalam penelitian, pemakaian busi tipe dingin untuk sepeda motor Honda Revo Fit 110 cc tahun 2012 dapat menurunkan konsumsi bahan bakar secara total. Hal ini dapat dilihat pada gambar 3 . 


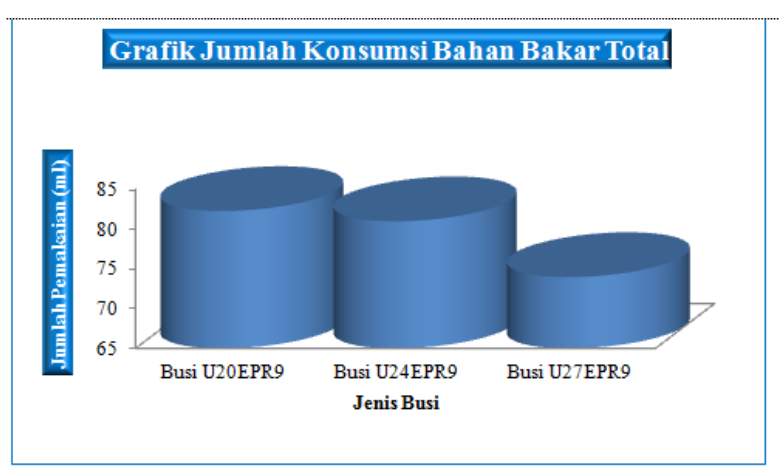

Gambar 3. Jumlah konsumsi bahan bakar secara total

\section{Konsentrasi Emisi Karbonmonoksida (CO)}

Dari hasil pengujian kadar emisi gas buang pada Tabel 1. jika dibuat tabel konsentrasi karbonmonoksida (CO) maka akan nampak seperti Gambar 4.

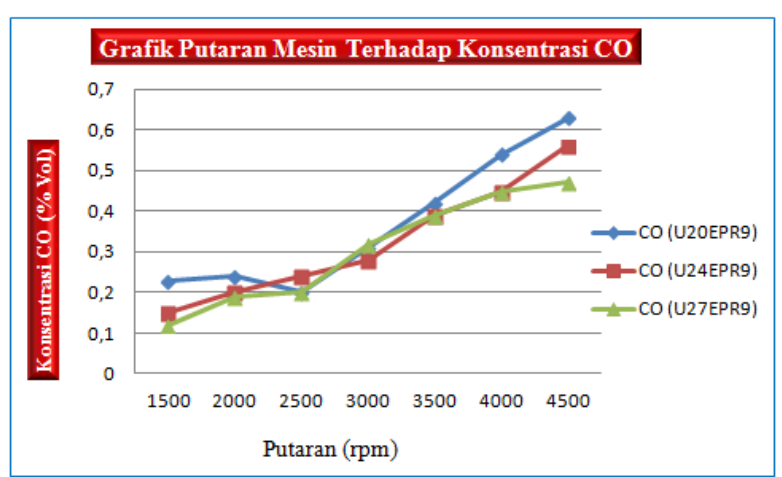

Gambar 4. Hubungan antara Putaran mesin terhadap emisi $\mathrm{CO}$

Secara umum, terjadi peningkatan gas $\mathrm{CO}$ pada masing-masing busi seiring peningkatan putaran mesin (rpm). Gas karbonmonoksida adalah gas yang relative tidak stabil dan cenderung bereaksi dengan unsur lain. Karbonmonoksida dapat diubah dengan mudah menjadi $\mathrm{CO}_{2}$ dengan bantuan sedikit oksigen dan panas. Dari data keseluruhan konsentrasi gas $\mathrm{CO}$ yang paling tinggi adalah pada pemakaian busi U20EPR9 dengan kadar emisi gas buang sebesar $0,63 \%$.

\section{Konsentrasi Emisi Hidrokarbon (HC)}

Dari hasil pengujian kadar emisi gas buang pada Tabel 1 jika dibuat tabel konsentrasihidrokarbon (HC) maka akan nampak seperti Gambar 5 di bawah ini:

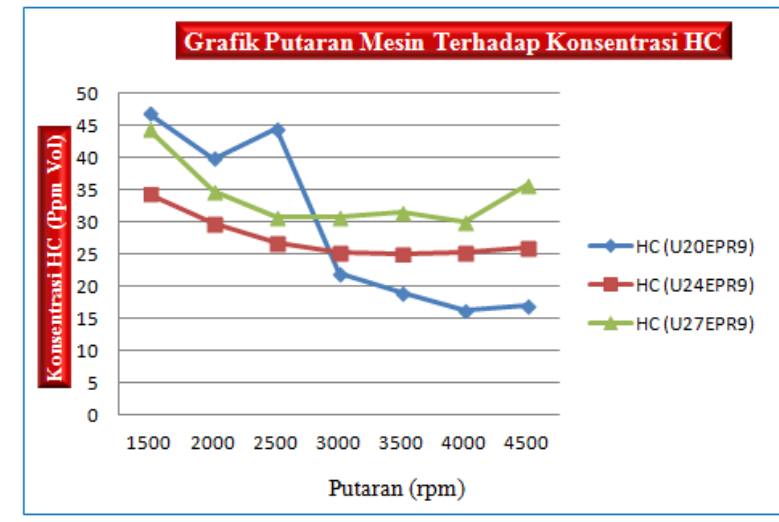

Gambar 5. Hubungan antara putaran mesin terhadap emisi HC

Bensin adalah senyawa hidrokarbon, jadi setiap HC yang didapat di gas buang menunjukkan adanya bensin yang tidak terbakar dan terbuang bersama sisa pembakaran. Dari data keseluruhan konsentrasi gas HC yang menunjukkan penurunan secara drastis pada setiap putaran mesin (rpm) adalah busi U20EPR9.

\section{Konsentrasi Emisi Karbondioksida $\left(\mathrm{CO}_{2}\right)$}

Dari hasil pengujian kadar emisi gas buang pada Tabel 1 jika dibuat tabel konsentrasi karbondioksida $\left(\mathrm{CO}_{2}\right)$ maka akan nampak seperti Gambar 6.

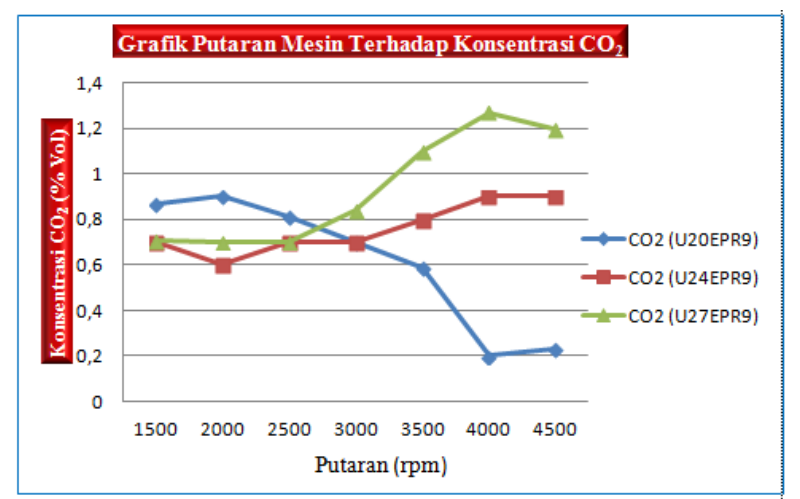

Gambar 6. Hubungan antara putaran mesin terhadap emisi $\mathrm{CO}_{2}$

Konsentrasi $\mathrm{CO}_{2}$ menunjukkan secara langsung status proses pembakaran di ruang bakar. Jika semakin tinggi maka semakin baik. Dari data keseluruhan konsentrasi gas $\mathrm{CO}_{2}$ yang paling tinggi adalah pada pemakaian busi U27EPR9. 


\section{Konsentrasi Emisi Oksigen $\left(\mathrm{O}_{2}\right)$}

Dari hasil pengujian kadar emisi gas buang pada Tabel 1 jika dibuat tabel konsentrasi Oksigen $\left(\mathrm{O}_{2}\right)$ maka akan nampak seperti Gambar 7.

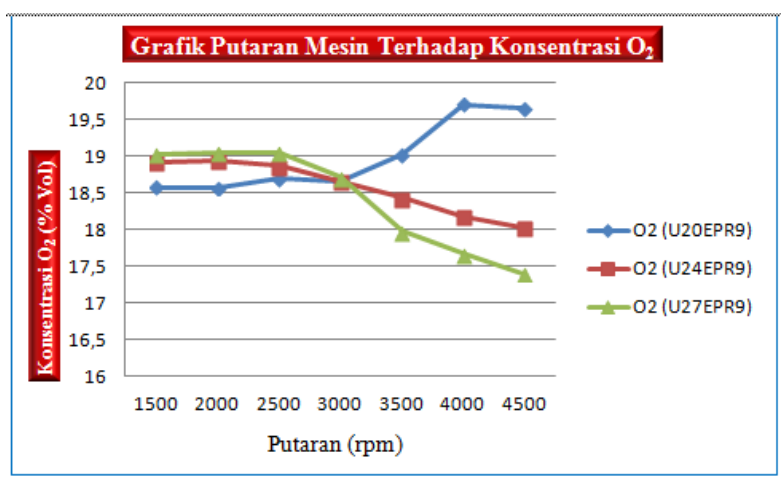

Gambar 7. Hubungan putaran mesin terhadap konsentrasi $\mathrm{O}_{2}$

Konsentrasi dari oksigen di gas buang kendaraan berbanding terbalik dengan konsentrasi $\mathrm{CO}_{2}$. untuk mendapatkan proses pembakaran yang sempurna, maka kadar oksigen yang masuk ke ruang bakar harus mencukupi untuk setiap molekul hidrokarbon. Dari data keseluruhan konsentrasi gas $\mathrm{O}_{2}$ yang dihasilkan busi U20EPR9 terus mengalami peningkatan seiring bertambahnya putaran mesin. Sedangkan pada busi U24EPR9 dan busi U27EPR9 terus mengalami penurunan kadar emisi $\mathrm{O}_{2}$ seiring bertambahnya putaran mesin.

Dari serangkaian penelitian yang dilakukan busi tipe dingin (U27EPR9) lebih efisien pemakaian bahan bakar dan lebih rendah emisi gas buang dibanding dengan busi tipe panas (U20EPR9) dan busi tipe sedang (U24EPR9). Hal ini disebabkan karena konstruksi busi tipe dingin memiliki ruangan gas/gas volume yang lebih kecil dibanding dengan busi tipe panas. Semakin kecil volumenya maka semakin besar panas yang dapat ditransfer/terbuang. Panas yang ada didalam ruang bakar disalurkan ke cylinder head melalui perantara busi. Semakin bagus proses transfer panas diruang bakar akan mengurangi resiko over heat, juga akan mengurangi resiko terjadinya "pre ignition" (pembakaran dini) yang dapat menyebabkan part mesin jadi cepat aus dan berpengruh terhadap efisiensi konsumsi bahan bakar.

\section{KESIMPULAN}

Dari serangkain penelitian, perhitungan, dan analisis data yang telah dilakukan, dapat disimpulkan bahwa penggunaan jenis busi dapat berpengaruh terhadap konsumsi bahan bakar dan kadar emisi gas buang sepeda motor Honda Revo Fit 110 cc tahun 2012.

1. Penggunaan jenis busi berdasarkan tingkat panas pada sepeda motor Honda Revo Fit 110 cc tahun 2012 berpengaruh terhadap konsumsi bahan bakar (fuel consumption). Pada penggunaan busi U20EPR9 konsumsi bahan bakar secara total pada semua putaran mesin (rpm) yang diujikan adalah sebesar $82,27 \mathrm{ml}$, sedangkan konsumsi bahan bakar busi U24EPR9 adalah 80,98 $\mathrm{ml}$ mengalami penurunan sebesar 1,5\% dibanding dengan busi U20EPR9. Pada pemakaian busi U27EPR9 konsumsi bahan bakar adalah $72,68 \mathrm{ml}$ mengalami penurunan sebesar $11,6 \%$ dari busi U20EPR9. Sedangkan konsumsi bahan bakar pada busi U27EPR9 mengalami penurunan $10,2 \%$ dari busi U24EPR9.

2. Penggunaan jenis busi berdasarkan tingkat panas pada sepeda motor Honda Revo Fit 110 cc tahun 2012 dapat berpengaruh terhadap kadar emisi gas buang seperti $\mathrm{CO}$, $\mathrm{HC}, \mathrm{O}_{2}$, dan $\mathrm{CO}_{2}$. Konsentrasi $\mathrm{CO}$ terendah dihasilkan oleh busi U27EPR9 pada putaran $1500 \mathrm{rpm}$ sebesar $0,12 \%$. Konsentrasi $\mathrm{CO}_{2}$ tertinggi dihasilkan oleh busi U27EPR9 pada putaran 4000 rpm sebesar 1,27\%. Konsentrasi $\mathrm{HC}$ terendah dihasilkan oleh busi U20EPR9 pada putaran $4000 \mathrm{rpm}$ sebesar 16,29 ppm. Sedangkan konsentrasi $\mathrm{O}_{2}$ mengalami peningkatan yang signifikan pada penggunaan busi U20EPR9, peningkatan tertinggi sebesar $19,70 \%$ didapatkan pada putaran $4000 \mathrm{rpm}$.

3. Secara keseluruhan dalam penelitian ini, konsentrasi $\mathrm{CO}_{2}$ yang tertinggi dihasilkan pada busi U27EPR9 pada putaran mesin 4000 rpm dengan konsumsi bahan bakar sebanyak 12,3 ml. Konsentrasi $\mathrm{CO}_{2}$ adalah 
$1,27 \%$ mengalami kenaikan pada grafik dan berbanding terbalik dengan konsentrasi $\mathrm{O}_{2}$ $(17,67 \%)$ yang mengalami penurunan pada grafik. Konsentrasi CO pada putaran ( $\mathrm{rpm}$ ) ini adalah 0,45\% dan HC sebesar 30 ppm. Ini menandakan pembakaran yang sempurna karena $\mathrm{CO}_{2}$ mengindikasikan proses pembakaran diruang bakar, jika semakin tinggi maka semakin baik.

4. Dari hasil penelitian ini, maka dapat disimpulkan bahwa pemakaian busi yang paling efisien penggunaan bahan bakar dan ramah terhadap lingkungan adalah busi U27EPR9.

\section{DAFTAR PUSTAKA}

[1] Ariani dan Silvia Farida. 2012. Hubungan Temperatur dengan Hambatan pada Busi Tipe Champion Z9Y, Denso U22FSU, dan NGK C7HSA. Jurnal Skripsi, jurusan Fisika FMIPA Universitas Negeri Malang. (http://karyailmiah.um.ac.id/index.php/fisika/article/vi ew/18460, diakses 25 November 2015)

[2] Jama Jalius. 2008. Teknik Sepeda Motor Jilid 2. Jakarta: Direktorat Pembinaan Sekolah Menengah Kejuruan Direktorat Jenderal Manajemen Pendidikan Dasar dan Menengah Departemen Pendidikan Nasional.

[3] Prayogi Sulis. 2013. Perbandingan Unjuk Kerja Mesin 4 Langkah Menggunakan Busi dan Koil Standar dengan Busi dan Koil Racing. Jurnal Skripsi, Jurusan Teknik Mesin, FT Universitas Negeri Jember.(http://repository.unej.ac.id/handle /123456789/4802, diakses 25 November 2015)

[4] Siswanto, M. 2008. Pengaruh Bahan Inti Elektroda Busi Platina dan Busi Iridium Terhadap Kadar Emisis Gas Buang CO dan HC Pada Mesin 4 Tak. Jurnal Skripsi, Jurusan Teknik Mesin, FT Universitas Negeri Malang.(http://karyailmiah.um.ac.id/index.php/TM/article/vie w/3198, diakses 25 November 2015)
[5] Somantri Ating dan Sambas Ali Muhidin. 2006. Aplikasi Statiska Dalam Penelitian. Bandung: CV Pustaka Setia

[6] Tjatur Sukma. 2013. Pemeliharaan Kelistrikan Sepeda Motor. Edisi Pertama 2013 Kementerian Pendidikan \& Kebudayaan Direktorat Jenderal Peningkatan Mutu Pendidik \& Tenaga Kependidikan. Jakarta: Kementerian Pendidikan \& Kebudayaan.

[7] Toyota Astra Motor. 1995. New Step 2 Training Manual. Jakarta: PT. Toyota Astra Motor, Training Center.

[8] TTL1, Maintenance Training, 2012. Pemeriksaan, Penyetelan, dan Penggantian Busi, PT Astra Honda Motor

[9] YTA , Bronze, 2004. Dasar-Dasar Mesin Sepeda Motor. Indonesia: Yamaha Motor CO.LTD 